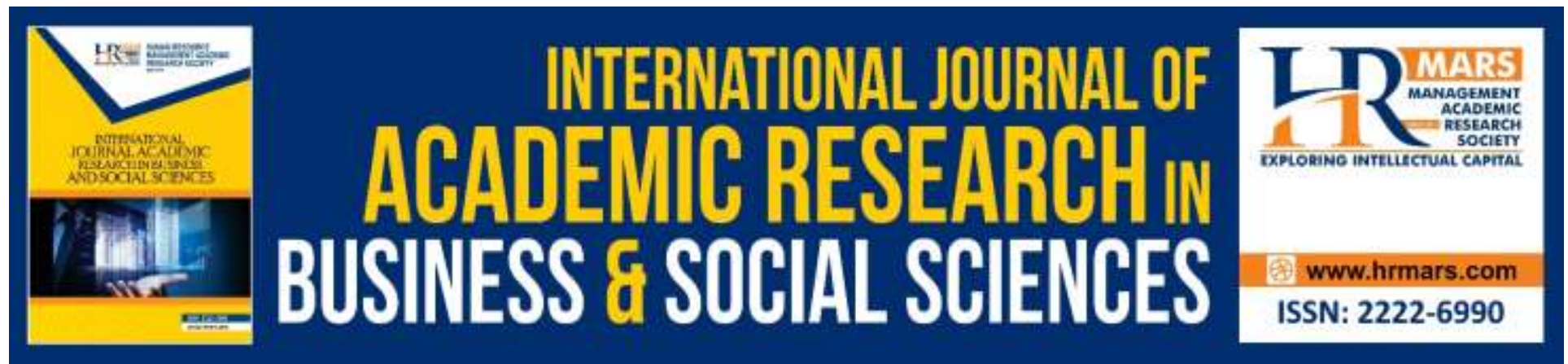

\title{
A Conceptual Framework for MakeUpBed Module in Helping Learning Disabilities Improving Make up Guest Bed Skills
}

\author{
Siti Maslina Ahad, Noor Aini Ahmad
}

To Link this Article: http://dx.doi.org/10.6007/IJARBSS/v9-i11/6644

DOI: 10.6007/IJARBSS/v9-i11/6644

Received: 10 October 2019, Revised: 30 October 2019, Accepted: 03 November 2019

Published Online: 27 November 2019

In-Text Citation: (Ahad \& Ahmad, 2019)

To Cite this Article: Ahad, S. M., \& Ahmad, N. A. 2019). A Conceptual Framework for MakeUpBed Module in Helping Learning Disabilities Improving Make up Guest Bed Skills. International Journal of Academic Research in Business and Social Sciences, 9(11), 1161-1171.

\section{Copyright: (C) 2019 The Author(s)}

Published by Human Resource Management Academic Research Society (www.hrmars.com)

This article is published under the Creative Commons Attribution (CC BY 4.0) license. Anyone may reproduce, distribute, translate and create derivative works of this article (for both commercial and non-commercial purposes), subject to full attribution to the original publication and authors. The full terms of this license may be seen at: http://creativecommons.org/licences/by/4.0/legalcode

Vol. 9, No. 11, 2019, Pg. 1161 - 1171

Full Terms \& Conditions of access and use can be found at http://hrmars.com/index.php/pages/detail/publication-ethics 


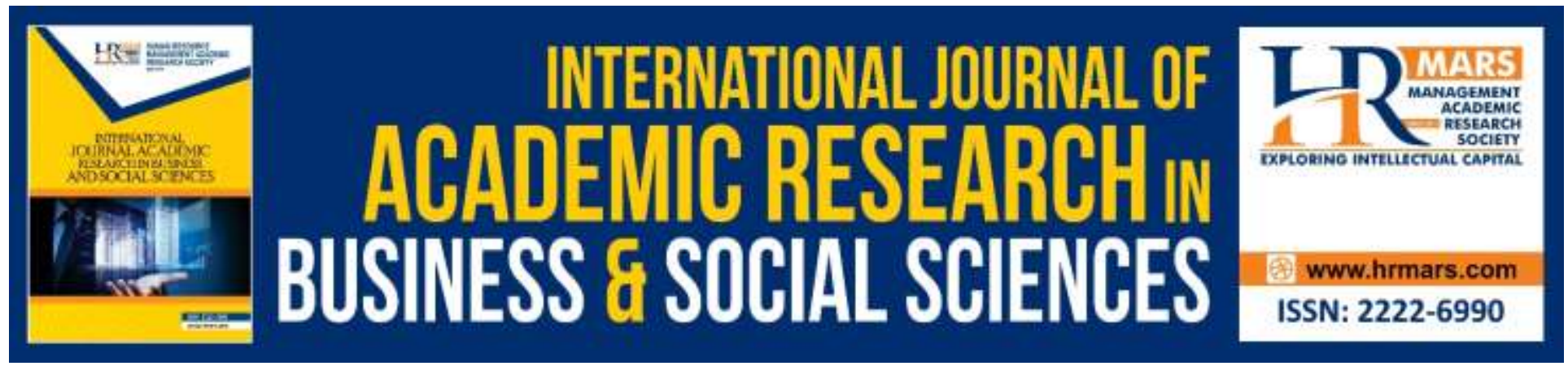

\title{
A Conceptual Framework for MakeUpBed Module in Helping Learning Disabilities Improving Make up Guest Bed Skills
}

\author{
Siti Maslina Ahad, Noor Aini Ahmad \\ Department of Special Education, Faculty of Human Development \\ Universiti Pendidikan Sultan Idris, Malaysia.
}

\begin{abstract}
Make up guest bed is thoroughly cleansing the guest's bed according to standard operating procedures. The neat and tidy guest bed is important. The first thing that will be evaluated by guests while entering the room is bed. The purpose of this study is to build the MakeUpBed module based on the multiple intelligence theory, VAK learning styles model (visual, auditory, kinesthetic), special education history, vocational education for special needs pupils with learning disabilities, special needs pupils with learning disabilities and make up guest bed skills. Based on the conceptual framework constructed, two phases are used which is module construction phase and module testing phase. The multiple intelligence theory founded by Gardner in 1983 and the V.A.K learning style model founded by Fleming in 2001 were used during the construction phase of the MakeUpBed module. The activities organized in the MakeUpBed Module are parallel to the VAK (Visual, Auditory and Kinesthetic) learning style models that focus on visual learning style, auditory learning style and kinesthetic learning style. Written Instructional materials (WIM) for Housekeeping operations (HT-050-3: 2012) developed by the Department of Skills Development, Ministry of Human Resources are used as references in carrying out the module construction process. The researcher chose to use the ADDIE Instructional Design Model as a step in building the module. The four sub modules contain in the MakeUpBed Module are (i) recognize beds, (ii) recognize linen, (iii) linen care and (iv) let's make up the guest bed. This study uses the quasi experimental design where the treatment group will use the MakeUpBed Module during the teaching and learning process. At the end of the teaching and learning, the pupils will be able to improve their bed making skills.

Keywords: Multiple Intelligence Theory, Vak Learning Style Model, Learning Disabilities, Module
\end{abstract}




\section{Introduction}

The history of special education in Malaysia has shown a positive development as early as the 1920 s with the opening of special school by volunteers. This development begins with the Report of the Cabinet Committee which reviewed the implementation of the 1979 education policy. As a result of this declaration, (i) inclusive education has commenced, (ii) the establishment of the Special Education Division (iii) education and employment opportunities for the people with disabilities (OKU) and (iv) curriculum that suits the needs of pupils with special needs (Ghani \& Ahmad, 2013). Next, government has set up the 2013 Education (Special Education) Regulations that have been gazetted by the government in 2012. This rule replaced the rules of education (Special Education) 1997 Part II 3 (2) (Government Gazette, 2013).

The government through the Ministry of Education Malaysia broadens the quality of education paths beginning with vocational education. This is stated in the displacement of a Malaysian Education Blueprint 2013-2025 (Ministry of Education, 2013). Vocational education for learning disabilities pupils began in 2002 in the Special Education Program involving pupils with learning disabilities in primary and secondary schools, where pre-vocational components are one of five areas in the curriculum. The curriculum in pre-vocational components consists of cooking, sewing, agriculture, trade, laundry and fisheries. (Abdullah, Yasin, Deli \& Abdullah, 2015). The Special Education Division, Ministry of Education Malaysia (MOE) is responsible for managing the governance of the Vocational Special Education Secondary School to provide educational opportunities for visual impaired, hearing impaired and learning disabilities (Norfishah, 2017). Up to 2017, there are four Vocational Special Education Secondary Schools which offer vocational education to pupils with special needs (Ministry of Education, 2018).

Pupils with learning disabilities at Vocational Special Education Secondary School who have graduated with Malaysian Skills Certificate will have certificate level one to level three issued by the Department of Skills Development, Ministry of Human Resources (Yusof, Ali, \& Salleh, 2014). Housekeeping Operation program (HT-050-3:2012) is based on the National Occupational Skills Standard (NOSS). NOSS is a document outlining the competencies required by a skilled worker working in Malaysia for a particular field and job level as well as the path to achieve the required level of competency. Learning materials, which are the main documents in accredited centers that carry out the Malaysian Skills Certificate, are Written Instructional Materials (Skills Development Department, 2013).

The use of technology in the classroom enhances enthusiasm and excitement among teachers and pupils (Wong, 2015). Knowledge and experience of teachers need to be improved especially for managing teaching and learning of pupils with learning disabilities (Raus, Rasdi, Alias, Ibrahim, Jaafar, 2013). 


\section{Literature Review}

The literature review include multiple intelligence theories, VAK learning style models (visual, auditory, kinesthetic), special education history, vocational education for learning disabilities pupils, pupils with learning disabilities and make up guest bed skills.

\section{Multiple Intelligence Theory}

Various type of intelligence will be enhanced from time to time in individual lives (Gardner, 1993). Developed by Harvard psychologist Howard Gardner in 1983, this theory states there are at least seven ways (human intelligence) to accept and understand the world. Howard Gardner, suggested that conventional perceptions of the I.Q. is limited (Armstrong, 2010). Gardner has described it as (i) logical mathematics, (ii) spatial/visual space, (iii) linguistics/language, (iv) kinesthetic, (v) music, (vi) interpersonal and (vii) intrapersonal (Gardner \& Hatch, 1989). In 2000, naturalist intelligence was incorporated into this theory as the eighth intelligence (Adcock, 2014). An effective teaching and learning environment can be created by manipulate pupils learning styles (Halim, Jusoh, Mokhtar \& Abdullah, 2016).

The intelligence that encompasses aspects of wisdom in the field of academic, thinking ability and problem-solving that fit the environment has pushed researchers to look at intelligence in a wider context (Sulaiman, 2013). The effectiveness of teaching and learning processes can be optimized if educators have knowledge about the pupils multiple intelligence profile (Lai \& Yap, 2016).

Therefore, continuous guidance should be given based on the pupil's ability until they reach the goal in accordance with the MakeUpBed Module that will be implemented on pupils from the Housekeeping Operations Program. The intelligence of a pupils with learning disabilities varies between individuals. Hence, the intelligence of each pupils, especially the body's kinesthetic intelligence, needs to be added to improve the skills of bed making. Using motor movement as part of the learning process, can help pupils learn better.

\section{VAK learning style model (Visual, Auditory, Kinesthetic)}

Learning style is an important indicator for improving the quality of a pupils teaching (Wahab, 2015). The VAK learning style theory is designed to illustrate how different learning processes are by pupils and was pioneered in 1987 by Neil Fleming (Johnston, Williams \& Ades, 2018). Kinesthetic pupils learn well using hand movements while auditory learning style involves the transfer of information through hearing. Visual learning styles involving the use of what is seen or observed. The findings show that kinesthetic learning styles are more commonly used rather than visual and auditory learning styles among high school pupils (Rajshree, 2013).

The auditory learning style emphasizes oral commands or through clear sentences. Pupils with kinesthetic learning styles will learn well when they have the opportunity to do their own activities taught by teachers (Fleming, 2001). Teachers need to encourage pupils to identify and set appropriate learning styles with them through teacher assistance (Tengku Ismadi Tengku 
Mohamad, 2015). In the context of this study, researchers will use these three learning styles as a framework in the module to be developed to help improve the skills of the pupils. The use of VAK learning styles model will make the learning strategies better. There are many factors that determine the best way people learn, Different views are noted about the impact of positive learning on pupils through learning style (Willis, 2017).

In summary, the three elements found in the VAK learning style are implemented in teaching and learning using the MakeUpBed Module with the aim of improving pupils achievement. The visual style is applied to the use of power point presentation, the auditory style is used during the teacher lecture method and the kinesthetic style is applied during demonstration and exploration methods. Hence, by applying the three learning styles provided, it is hoped that this strategy can be used to improve pupils achievement.

\section{Special Education History}

Society in the days of Greek and Roman civilization believe pupils with disabilities was unlucky (Ghani \& Ahmad, 2011). In the United States, special education for pupils with disabilities begins in the 19th century for blind or deaf children (or both) or have intellectual disabilities. Before these special schools were established, children with disabilities just left at the house. National School which began in the mid-1800s usually did not accommodate pupils with special needs (Kauffman, Hallahan, Pullen \& Badar, 2018). With the establishment of Public Law (PL Law 94142 in 1975, each state in the western country should provide free education in the public school system to all special children (Mohamed, 2005). Individual with Disabilities Education Act entitles every student with special needs in the United States to receive appropriate public education through special education services (Lipkin \& Okamoto, 2015). In England, there are legislative developments in parallel with the United States. Among the major legislations are (i) Education Act 1981, (ii) Education Act 1993, (iii) Disability Discrimination Act 1995 and (iv) Special Education Needs and Disability Act 2001(Farrell, 2009). In Malaysia, the setting up of the earliest special education school was Special School for visual impaired pupils, Princess Elizabeth's Special Education Primary School in Johor Baharu by the British Federal Government. Meanwhile, a special school for hearing impaired pupils was established in 1954, namely Federal Special Education National School (Lay \& Hui 2014). In the 1980s and 1990s, Malaysia began sending education specialists to gain knowledge in special education (Jelas \& Ali, 2014).

\section{Vocational Education for Learning Disabilities}

Vocational education is known as vocational and technical education (Vincent, 2016). Vocational education provided at school or in a skilled institution is intended to equip individuals with job skills (Kamat \& David, 2007). Technical and Vocational Education (TVET) aims to develop highskilled workers (Rahman, Hanafi, Ahmad, 2014). Vocational education involves practical training as well as theoretical learning appropriate to various fields of work (Organization for Economic Co-Operation and Development, 2010). Technical and Vocational Education is seen to be 
important in helping the country achieve its aspirations as a developed nation by the year 2020 (Minghat, Yasin, Subari, Noordin, 2013).

The findings show that the disabled trainees are seen to have limitations in terms of efficiency to achieve targeted goals (Latib, Subari, Ahmad, Udin, Daley, 2017). Only 28 percent of Malaysian workers are classified as skilled and semi-skilled workers. This shows that our country is lagging behind other developed countries (Rus, Yasin, Yunus, Bekri, Rahim \& Ismail, 2015). Current challenges and obstacles in the involvement of learning disability while pursuing vocational education programs are the lack of teaching aids, lack of appropriate educational facilities, lack of trained instructors and isolation of pupils with disabilities in education (Malle, Yehualawork, Pirttimaa, Raija \& Saloviita, Timo, 2015). An alternative approach that can contribute significantly to the teaching and learning of technical and vocational education can be done using the SelfLearning Module. Module is a set of learning activities arranged systematically to help pupils achieve learning objectives. Modules contain subjects, exercise and others that are implemented separately to achieve a skills (Madmor, Kiong, Azman, Rus, Hanapi \& Yunos, 2017).

\section{Special Needs Pupils with Learning Disabilities}

Special needs pupils with learning disabilities have experienced the slow development from mainstream pupils and problems to adapt to the environment (Salim, 2015). In terms of intellect, special needs pupils also have naturally existing talents. This study also found that fellow friends did not know deeply about special needs pupils. However, the findings show that teachers and families only have little knowledge of them (Lee, Awang \& Surat, 2017). Teachers have difficulty to teach them because they easy to get bored, inferiority, difficult to understand the instruction and the difficulty in identifying abilities, interests and self-reliance (Ali, 2013).

\section{Make up Guest Bed Skills}

In a hotel, making a guest bed is part of a routine task for room attendance under Housekeeping Operations Department. Make up bed is all about changing of dirty linen to the clean one and tidy up bed for the comfort of guests (Chon \& Maier, 2009). Servicing guest room properly begins with the right approach and procedure. The housekeeping operations department need to ensure the hygiene, courteous and politeness are at the highest level every time (Casado, 2011). The main reason guests choose not to return is a dirty room (Aziz, Shahril \& Tarmudi, 2012). Task force as a room attendance requires high commitment and skill in ensuring the quality of a room is at highest level and meets the specifications of hotel guests. One of the tasks in Housekeeping Operation is the task to make up a guest bed that must be done by room attendance. The neat and tidy guest bed is very important to the guests (Agustinus, 1994). Room attendance are responsible for cleaning the hotel room (Correa \& Morrone, 2012). Room attendance comprise the largest working group in the hotel industry (Rosemberg \& Li, 2018).

\section{Conceptual Framework}


Based on the past literature, multiple intelligence theory and V.A.K learning styles model were found as a factor to improve performance among pupils. This study is aimed to build the MakeUpBed module in order to improve make up guest bed skills amongst learning disabilities in vocational schools. There are two phases in the study which are modules construction phase and module testing phase. There are eight intelligences that have been recorded: (i) logicalmathematical intelligence, (ii) linguistic-language intelligence, (iii) musical intelligence (iv) spatial visual space intelligence, (v) body kinestetic intelligence (vi) interpersonal intelligence Intrapersonal intelligence and (viii) naturalist. This theory shows that Individual intelligence can be improved through education and training (Gardner, 1993).

In this study, the researcher focused on the kinesthetic intelligence of the body in relation to the ability to make up a guest bed. The activities organized in the MakeUpBed Module are parallel to the VAK learning style (Visual, Auditori and Kinesthetic) which focuses on visual learning styles, auditory learning styles and kinesthetic learning styles. Written Instructional materials (WIM) housekeeping operations (HT-050-3: 2012) developed by the Department of Skills Development, is used as a reference in carrying out the module construction process. The researcher choose to use the ADDIE Instructional Design Model as a step in building the module. Next, this module will be test to the pupils with learning disabilities studying Housekeeping Operations programme at Vocational Special Education Secondary Schools. After three months of treatment, this experiment group are expected to be able to improve their makeup bed skills. As a conclusion, MakeUpBed Module is designed to improve the achievements of learning disabilities pupils in bed making skills. Figure 1.1 shows a conceptual framework for the construction and testing of the MakeUpBed module to help pupils with learning disabilities.

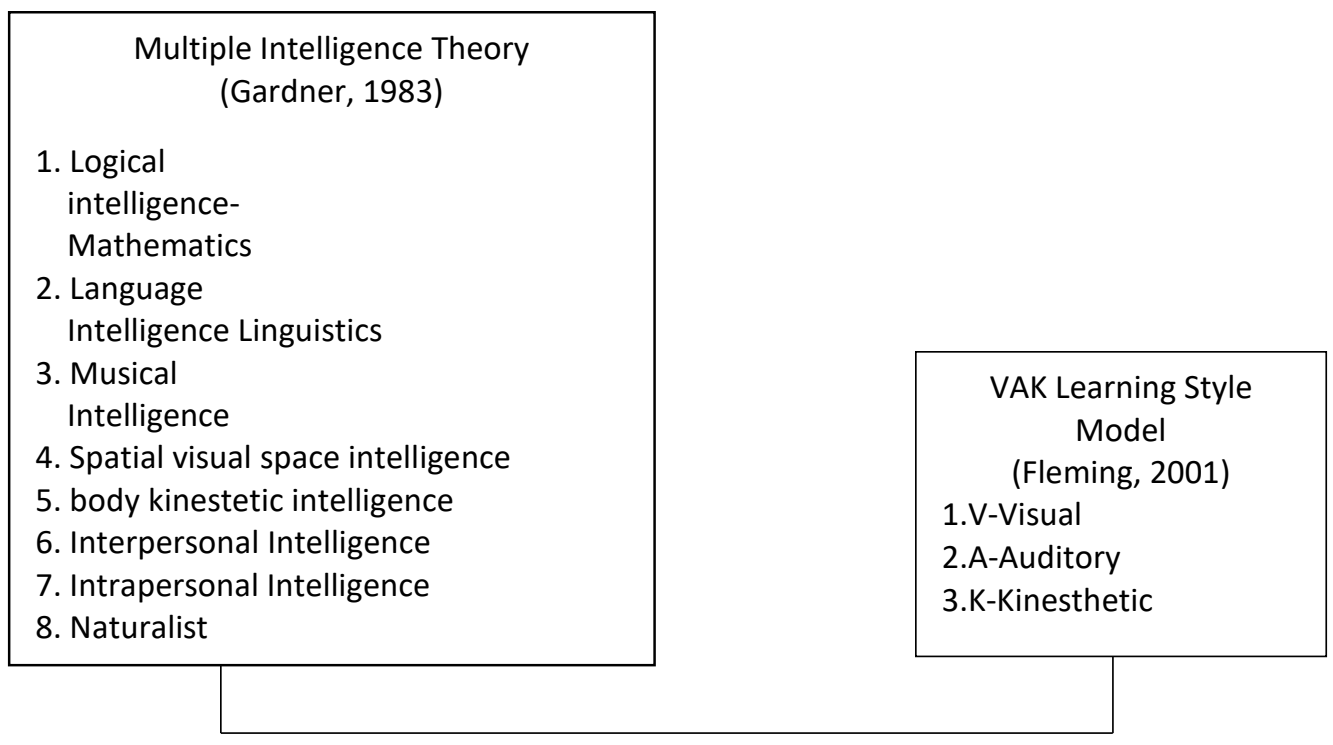


Figure 1.1: A conceptual framework of the MakeUpBed module to help pupils with learning disabilities to improve their makeup bed skills.

\section{Conclusion and Discussion}

Literature review has been developed based on multiple intelligence theories, VAK learning styles models (visual, auditory, kinestetic), special education history, vocational education for pupils with learning disabilities, special needs pupils with learning disabilities and make up bed skills.

In short, theory of multiple intelligence contains a variety of intelligence elements that can represent pupils with learning disabilities in learning. The VAK learning style model is chosen as vocational education covers the three elements in the VAK learning style model. Special education history has shown the development of special education that involves pupils with learning disabilities in the field of vocational education offered.

The use of the MakeUpBed Module is necessary in ensuring that the skills they wish to deliver are well received by pupils with learning disabilities who are pursuing vocational education. After undergoing treatment using the MakeUpBed Module, pupils are able to master the makeup bed skills. Interventions that are appropriate to the level of pupils with learning disabilities are hope can improving the skills of makeup bed among pupils. As pupils with learning disabilities faced various challenges to cope with the skills channel to them, proper approaches can enhance and maximize academic achievement of them.

\section{Acknowledgement}

I would like to put my very high gratitude to Ministry of Education (Moe) for the sponsorship throughout my studies. I also also would like to show my gratitude to Universiti Pendidikan Sultan Idris who provided an expertise that greatly assisted this research.

\section{Corresponding Author}

Siti Maslina Ahad

Department of Special Education

Faculty of Human Development

Universiti Pendidikan Sultan Idris

Perak Malaysia.

Email: sitimaslinaa11@yahoo.com

\section{References}

Adcock, P. K. (2014). The longevity of multiple intelligence theory in education. Delta Kappa Gamma Bulletin, 80(4), 50-57.

Aliza, A. (2013). The issues in implementing transition program for special needs students. Asean Social Science. 9, 9-14. 
INTERNATIONAL JOURNAL OF ACADEMIC RESEARCH IN BUSINESS AND SOCIAL SCIENCES

Vol. 9, No. 11, November, 2019, E-ISSN: 2222-6990 @ 2019 HRMARS

Armstrong, T. (2010). Neurodiversity: discovery the extraordinary gifts of autism, ADHD, dyslexia and other brain differences. Cambridge. MA: DaCapo Press.

Yusof, A. M., Ali, M. M., \& Salleh, A. M. (2014). Employability of vocational school leavers with disabilities. Procedia Social and Behavioral Sciences, 112, 1064-1069.

Minghat, A. D., Yasin, R. M., Subari, K., Noordin, M. K. (2013). Strategi kelestarian pembangunan pendidikan teknikal dan vokasional (PTV). International Seminar on Quality and Affordable Education, 493-503.

Aziz, A. A., Shahril, A. M., \& Tarmudi, S. (2012). Introduction to housekeeping practices. Selangor: Penerbit Press Universiti Teknologi MARA.

Agustinus, D. (1994). Tata graha hotel (housekeeping). Jakarta: PT.Gramedia Widiasarana Indonesia.

Rahman, A. A., Hanafi, N. M., Mukhtar, M. I., \& Ahmad, J. (2014). Assessment practices for competency based education and in vocational college. Malaysia International Conference on Education \& Educational Psychology, 112, 1070-1076.

Casado, M. A. (2011). Housekeeping management $2^{\text {nd }}$ Edition. New Jersey: Wiley.

Chon, K. S., \& Maier, T. A. (2009). Welcome to hospitality. $3^{\text {rd }}$ Edition. New York. U.S.A: Delmar.

Farrell, M. (2009). Foundations of special education: an introduction. United Kingdom: WileyBlackwell.

Sulaiman, H. B. (2013). Hubungan antara kecerdasan emosi dengan gaya asuhan ibu bapa dalam kalangan remaja sekolah. Tesis ljazah Doktor falsafah. Universiti Malaya. Kuala Lumpur.

Howard, G. (1993). Multiple intelligences: The theory in practice. New York: Basic Books.

Howard, G., \& Thomas, H. (1989) Educational implications of the theory of multiple intelligences. Educational Researcher. 18(8) 4-10.

Johnston, L., Williams, B. S., \& Ades, A. (2018). Education for ECMO providers: Using education science to bridge the gap between clinical and educational expertise. Seminars in Perinatology. 42(2), 138-146.

Jamila, K. A. M. (2005). Pendidikan khas untuk kanak-kanak istimewa. Kuala Lumpur: PTS Profesional.

Kauffman, J., Hallahan, D., Pullen, P., Badar, J. (2018). Special education. New York: Routledge.

Kementerian Pendidikan Malaysia (2012). Pelan pembangunan pendidikan Malaysia 2013-2025. Kementerian Pendidikan Malaysia, Putrajaya.

Kementerian Pendidikan Malaysia (2017). Data pendidikan khas 2017. Dari laman sesawang https://moe.gov.my/images/KPM/BP Khas/DATA/Data Pendidikan Khas 2017.pdf. Tarikh capaian: 12 Ogos 2018.

Lai, H. Y., \& Yap, S. L. (2016). Application of multiple intelligence theory in the assessment for learning. In: Tang S., Logonnathan L. (eds) Assessment for Within and Beyond the Classroom. Singapore: Springer.

Lay, W. L., \& Hui, M. L. (2014). The evolution of special education in Malaysia. British journal of special education. 41 (1), 42-58. 
Lee, S. P., Awang, M. M., \& Surat, S. (2017). Community perspectives on children with special needs. Journal of Sustainable Development Education and Research, 1(1), 61-68.

Lipkin, P. H., \& Okamoto, J. (2015). The individuals with disabilities education act (idea) for children with special educational needs. Council on Children with Disabilities and Council on School Health. Pediatrics. 136(6), 1650-1662.

Malle, A. Y., Pirttimaa, R., \& Timo, S. (2015). Inclusion of students with disabilities in formal vocational education programs in Ethiopia International Journal of Special Education, 30(2), 57-67.

Ghani, M. Z., \& Ahmad, A. C. (2013). Pengantar pendidikan khas. Pulau Pinang: Penerbitan Universiti Sains Malaysia.

Ghani, M. Z., Ahmad, A. C., \& Isa, Z. M. (2014). Masalah pembelajaran. Tanjong Malim Perak: Penerbit Universiti Sultan Idris.

Rabi, N. M. (2017). Transformasi pendidikan murid kurang upaya. Tanjong Malim. Perak: Penerbitan Universiti Pendidikan Sultan Idris.

Halim, N. D. A., Jusoh, A., Mokhtar, M., \& Abdullah, A. H. (2016). Effectiveness of using bizzapss in enhancing students' achievement with different learning styles. Persidangan RCEE, 1, 260-264.

Abdullah, N., Yasin, M. H. M., Deli, A. A. A., \& Abdullah, N. A. (2015). Vocational education as a career pathway for students with learning disabilities: Issues and obstacles in the implementation. International Journal of Education and Social Science, 2(3), 98-104.

Rajshree, S. V. (2013). Learning style and academic achievement of secondary school students. Voice of Research. 1(4), 1-4.

Salim, R. (2015). Pengurusan Pendidikan Khas: Masalah Pembelajaran. Kuala Lumpur. Dewan Bahasa dan Pustaka.

Rus, R. C., Yasin, R. M., Yunus, F. A. N., Rahim, M. B., Ismail, I. M. (2015). Skilling for job: A grounded theory of vocational training at industrial training institutes of Malaysia. World Congress on Technical and Vocational Education and Training (WoCTVET), Procedia-Social and Behavioral Sciences 204, 198 - 205.

Rosemberg, M. A. S., \& Li, Y. (2018). Effort-reward imbalance and work productivity among hotel housekeeping employees: A pilot study. Workplace Health \& Safety, 66(11), 516- 521.

Wahab, R. B. A. (2015). Gaya pembelajaran dalam kalangan pelajar kurang upaya tumpuan dan hiperaktif (ADHD). Tesis ljazah Doktor Falsafah. Universiti Sains Malaysia. Pulau Pinang.

Silva-Júnior, J. S., Correa, L. R. C., \& Morrone, L. C. (2012). Evaluation of lumbar overload in hotel maids. Work, 41, 2496-2498.

Mohamad, T. I. T. (2015). Motivasi alihan pelajar. Selangor: PTS Millennia Sdn. Bhd.

Vincent, C. (2016). Vocational education and technical training. United Stated: Willford Press.

Wang, I. W. (2015). The wear out effect of a game-based student response system. Computers \& Education, 82, 217-22.

Warta Kerajaan Persekutuan. (2013). Peraturan-peraturan pendidikan (pendidikan khas) 2013. 
Willis, S. (2017). Literature review on the use of VAK learning strategies. The Step Journal. 4(2), 90-94.

Jelas, Z. M., \& Ali, M. M. (2014). Inclusive education in Malaysia: Policy and practice. International Journal of Inclusive Education, 18(10), 991-1003. 